\title{
Supporting Oxygenation in Acute Respiratory Failure
}

\author{
Neil R MacIntyre MD FAARC
}

\author{
Introduction \\ Toxicities Associated With Strategies to Support Blood Oxygenation and \\ Tissue Oxygen Delivery \\ Ventilator-Induced Lung Injury \\ Oxygen Toxicity \\ Toxicities Associated With Other Strategies to Support Oxygen Delivery to \\ Tissues \\ Revisiting the Physiology of Tissue Hypoxia \\ So What Are Reasonable Oxygenation Targets Today? \\ Balancing Benefits and Risks of Specific Oxygenation Support Strategies \\ Summary
}

\begin{abstract}
Strategies to support oxygenation can cause substantial harm through lung stretch injury, oxygen toxicity, transfusion risks and cardiac over-stimulation. Traditional goals of maintaining near normal cardiorespiratory parameters are most likely overly simplistic and are insensitive and nonspecific for tissue hypoxic effects. In order to reduce iatrogenic harm, it is conceivable that clinicians could be comfortable with lower levels of arterial oxygen content (eg, oxyhemoglobin values of $<88 \%$ : so called "permissive hypoxemia"), provided that there are ways to effectively monitor tissue hypoxia. We can learn more about hypoxic compensatory mechanisms from the fetus and from high altitude residents. We also need to learn better ways of monitoring tissue oxygenation, especially in "mission critical" tissues. Ultimately clinical trials will be needed to determine appropriate oxygenation targets to allow permissive hypoxemia. Key words: oxygenation; oxygen; oxygen toxicity; hypoxia; hypoxemia. [Respir Care 2013;58(1):142-148. () 2013 Daedalus Enterprises]
\end{abstract}

\section{Introduction}

In acute hypoxemic respiratory failure there are a number of strategies to support oxygen delivery to vital organs. For support of the respiratory system, 2 basic tools are available: supplemental oxygen and mechanical ventilation. Supplemental oxygen raises the alveolar $\mathrm{P}_{\mathrm{O}_{2}}$, which,

Neil R MacIntyre MD FAARC is affiliated with the Division of Pulmonary and Critical Care Medicine, Duke University Medical Center, Durham, North Carolina.

Dr MacIntyre presented a version of this paper at the 50th RESPIRATORY CARE Journal Conference, "Oxygen," held April 13-14, 2012, in San Francisco, California. in turn, for a given alveolar-arterial oxygen difference, raises $\mathrm{P}_{\mathrm{aO}}$. Positive-pressure ventilation works through 2 mechanisms. During inspiration, alveolar ventilation is supported by positive pressure breaths, improving alveolar $\mathrm{P}_{\mathrm{O}_{2}}$. During expiration, PEEP maintains alveolar patency, thereby improving ventilation-perfusion matching and the alveolar-arterial oxygen difference. ${ }^{1}$

\footnotetext{
The author has disclosed no conflicts of interest.
}

Correspondence: Neil R MacIntyre MD FAARC, Division of Pulmonary and Critical Care Medicine, Duke University Hospital, Box 3911, Durham NC 27710. E-mail: neil.macintyre@duke.edu.

DOI: $10.4187 /$ respcare. 02087 
In addition to respiratory support, there are 2 other clinical strategies to support oxygen delivery to tissues: support of cardiac output, and support of hemoglobin concentration. ${ }^{1}$ Cardiac output is supported by both proper fluid loading and inotropes; hemoglobin concentration is supported through red blood cell transfusions.

Unfortunately, while all of these approaches can help with tissue oxygenation, they all have substantial toxicities that can cause patient harm (iatrogenic injury). As described in more detail in the next section, high inspired concentrations of oxygen, high mechanical ventilation pressures/volumes, inotrope use, and red blood cell transfusions can all cause a variety of injuries that have become increasingly apparent over the last several decades. ${ }^{2-8}$ This has led to a rethinking of the targets for blood oxygenation and tissue oxygen delivery. Like so many other issues in clinical medicine, this rethinking addresses the balance clinicians want to achieve between the benefits of an intervention and its toxicities. The remainder of this paper will focus on the injuries that can occur during oxygenation support of acute respiratory failure and then will revisit physiology of tissue hypoxia to reexamine what the goals for oxygenation and oxygen delivery might be in the future.

\section{Toxicities Associated With Strategies to Support Blood Oxygenation and Tissue Oxygen Delivery}

\section{Ventilator-Induced Lung Injury}

The lung can be injured when it is stretched excessively by positive-pressure ventilation. ${ }^{3,4}$ The most well recognized injury is that of alveolar rupture, presenting as extraalveolar air in the mediastinum, pericardium, subcutaneous tissue, pleura, and even vasculature. ${ }^{9}$ A parenchymal lung injury not associated with extra-alveolar air (ventilator-induced lung injury or VILI) can also be produced by mechanical ventilation strategies that stretch the lungs beyond the normal maximum (ie, transpulmonary distending pressures of $30-35 \mathrm{~cm} \mathrm{H}_{2} \mathrm{O}$ ). ${ }^{3,4}$ This is termed excessive lung "stress" in engineering parlance. Importantly, VILI is most likely more than simply a consequence of excessive lung stress. Excessive tidal stretch (ie, repetitive cycling of the lung with higher than normal tidal volumes-excessive lung "strain"), even in the setting of acceptable lung stress, may also contribute to VILI. ${ }^{10,11}$

Other ventilatory pattern factors may also be involved in the development of VILI. These include frequency of stretch $^{12}$ and the acceleration/velocity of stretch. ${ }^{13}$ Although VILI may not be impacted by fixed atelectasis, it does appear to be potentiated by a shear stress phenomenon that occurs when injured alveoli are repetitively opened and collapsed during the ventilatory cycle (ie, cyclical atelectasis). ${ }^{14-16}$
VILI is manifest pathologically as diffuse alveolar damage. ${ }^{4}$ Moreover, VILI is associated with cytokine release ${ }^{17,18}$ and bacterial translocation, ${ }^{19}$ which are implicated in the systemic inflammatory response with multiorgan dysfunction that results in VILI associated mortality.

VILI most likely develops regionally when low resistance/high compliance units receive a disproportionately high regional tidal volume in the setting of high alveolar distending pressures. Regional protection of these healthier lung units is the rationale for using "lung-protective" ventilator strategies that accept abnormal values for $\mathrm{pH} /$ $\mathrm{P}_{\mathrm{CO}_{2}}$ and $\mathrm{P}_{\mathrm{O}_{2}}$ ("permissive" hypercapnia and hypoxemia, respectively) in exchange for lower (and safer) distending pressures.

\section{Oxygen Toxicity}

It has also been known for decades that high concentrations of inspired oxygen can produce free radicals and produce an oxygen injury in the lungs. ${ }^{2}$ Indeed, in small animals 100\% oxygen can be lethal in a matter of hours. In primates, however, oxygen induced injury appears to be a slower process. For example, non-human primates develop clinically important lung injury in 1-2 days when exposed to $\mathrm{F}_{\mathrm{IO}_{2}}$ values of $1.0,{ }^{20}$ but this injury may take up to 2 weeks to develop at an $\mathrm{F}_{\mathrm{IO}_{2}}$ of 0.6. ${ }^{21}$ Importantly, the presence of various disease states and inflammatory processes may modulate the response to oxygen toxicity in the lung. It is thus not clear what the "safe" oxygen concentration or duration of exposure is in sick humans. Most consensus groups have argued that $\mathrm{F}_{\mathrm{IO}_{2}}$ values $<0.4$ are safe for prolonged periods of time and that $\mathrm{F}_{\mathrm{IO}_{2}}$ values of $>0.8$ should be avoided if at all possible.

While we think of oxygen toxicity as being primarily a lung phenomenon, one should not forget that high levels of oxygen in other tissues may also produce adverse effects. Mechanisms involved could include free radical injury in the tissues as well as the effects of hyperoxia on the distribution of perfusion at the tissue level. ${ }^{22}$ These effects are most obvious in the neonate developing retrolental hyperplasia after exposure to high oxygen concentrations. ${ }^{23}$ However, it could conceptually occur in many other organ systems in both the infant and the adult. This is not a well studied area, but there is evidence in the cardiology literature that routine use of supplemental $\mathrm{O}_{2}$ in patients with acute myocardial infarction who are not hypoxemic may worsen outcomes. ${ }^{24}$ It is also interesting that several recent reports have noted that hospitalized patients who are given supplemental oxygen that results in unnecessarily high levels of $\mathrm{P}_{\mathrm{aO}_{2}}$ (generally above $120 \mathrm{~mm} \mathrm{Hg}$ ) may actually have a worsening of clinical outcomes. ${ }^{25,26}$ However, this is not a universal finding, and there are conflicting data about the harm from hyperoxia in post cardiac resuscitation or mechanically ventilated patients. ${ }^{27-30}$ At the pres- 
Supporting Oxygenation in Acute Respiratory Failure

Table. Regional Differences in Blood Flow, Oxygen Use, and $\mathrm{P}_{\mathrm{O}_{2}}$

\begin{tabular}{|c|c|c|c|c|c|c|}
\hline Organ & $\begin{array}{l}\text { Blood Flow } \\
(\mathrm{mL} / \mathrm{min})\end{array}$ & $\begin{array}{l}\% \text { of } \\
\text { Cardiac } \\
\text { Output }\end{array}$ & $\begin{array}{c}\mathrm{O}_{2} \text { Use } \\
(\mathrm{mL} / \mathrm{min})\end{array}$ & $\begin{array}{l}\% \text { of } \\
\text { Total }\end{array}$ & $\begin{array}{c}\text { Arteriovenous } \mathrm{O}_{2} \\
\left(\mathrm{~mL} \mathrm{O}_{2} / 100 \mathrm{~mL}\right)\end{array}$ & $\begin{array}{l}\text { Venous } \mathrm{P}_{\mathrm{O}_{2}} \\
(\mathrm{~mm} \mathrm{Hg})\end{array}$ \\
\hline Heart & 250 & 4 & 26 & 11 & 11 & 23 \\
\hline Skeletal muscles & 1,200 & 21 & 72 & 30 & 8 & 34 \\
\hline Brain & 750 & 13 & 48 & 20 & 6 & 33 \\
\hline Splanchnic & 1,400 & 24 & 60 & 25 & 4 & 43 \\
\hline Kidneys & 1,100 & 19 & 17 & 7 & 1 & 56 \\
\hline Skin & 500 & 9 & 5 & 2 & 1 & 60 \\
\hline Other & 600 & 10 & 12 & 5 & & \\
\hline Totals & 5,800 & 100 & 240 & 100 & $4^{*}$ & $46^{*}$ \\
\hline $\begin{array}{l}\text { * Average } \\
\text { (Data from Reference } 31 .\end{array}$ & & & & & & \\
\hline
\end{tabular}

ent time, given the potential harm and the lack of benefit to hyperoxia, clinical targets should not exceed physiologic thresholds.

\section{Toxicities Associated With Other Strategies to Support Oxygen Delivery to Tissues}

Oxygen delivery to tissues involves more than the lungs transporting $\mathrm{O}_{2}$ from the environment to the alveolus and into the pulmonary capillary blood. Because of the poor solubility of $\mathrm{O}_{2}$ in plasma, the oxygen carrying molecule hemoglobin is required to provide adequate oxygen content in the blood. In addition, the cardiac pump is required to deliver the oxygenated blood to the capillary beds of the vital organs. These relationships are described in the equations:

Oxygen delivery $\left(\mathrm{D}_{\mathrm{O}_{2}}\right)=$ oxygen content $\left(\mathrm{C}_{\mathrm{aO}_{2}}\right)$

$$
\times \text { cardiac output }(\mathrm{CO})
$$

$\mathrm{D}_{\mathrm{O}_{2}}=\left(\mathrm{P}_{\mathrm{O}_{2}} \times\right.$ hemoglobin concentration

$$
\times \text { hemoglobin oxygen binding) } \times \mathrm{CO}
$$

Normal values: $1,000 \mathrm{~mL} \mathrm{O}_{2} / \mathrm{min}$

$$
\begin{aligned}
=(100 \mathrm{~mm} \mathrm{Hg} \times 0.15 \mathrm{~g} \text { hemoglobin } / \mathrm{mL} \\
\left.\quad \times 0.0134 \mathrm{~mL} \mathrm{O}_{2} / \mathrm{mm} \mathrm{Hg}\right) \times 5,000 \mathrm{~mL} / \mathrm{min}
\end{aligned}
$$

Hemoglobin concentration can be augmented with red blood cell transfusions. However, there are substantial risks. Transfusions can produce fluid overload, carry infection risks, and produce immune reactions from mismatched blood. ${ }^{7,8}$ Red blood cell transfusions can also cause a direct injury to the pulmonary capillary bed (transfusion related acute lung injury). ${ }^{8}$ Finally, transfused blood loses its ability to effectively carry oxygen and properly enter tissue capillary beds the longer it is stored. ${ }^{7}$

Cardiac output can be managed with fluid manipulations and inotropes. Fluid manipulations, however, can "cut both ways." Adequate cardiac filling is required for effective ventricular function. On the other hand, excessive fluids can both flood the lungs and overdistend the ventricles, compromising ventricular contraction. Inotropes directly stimulate the heart, and vasopressors constrict blood vessels to maintain arterial perfusion pressure. Both, however, can elicit cardiac ischemia and produce dysrhythmias. ${ }^{6}$

\section{Revisiting the Physiology of Tissue Hypoxia}

As noted above, normal oxygen delivery to the tissues at rest is roughly $1,000 \mathrm{~mL} / \mathrm{min}$, and normal oxygen content is roughly $200 \mathrm{~mL} / \mathrm{L}$ with an arterial blood $\mathrm{P}_{\mathrm{O}_{2}}$ of near $100 \mathrm{~mm} \mathrm{Hg.}{ }^{1,26}$ As blood traverses the "average" tissue capillary bed, approximately $25 \%$ of this oxygen is extracted resulting in mixed venous blood $\mathrm{O}_{2}$ content of $150 \mathrm{~mL} / \mathrm{L}$ and a mixed venous $\mathrm{P}_{\mathrm{O}_{2}}$ of $40 \mathrm{~mm} \mathrm{Hg}$. This translates into a total body $\mathrm{O}_{2}$ consumption $\left(\dot{\mathrm{V}}_{\mathrm{O}_{2}}\right)$ of approximately $250 \mathrm{~mL} / \mathrm{min}$ at rest. In the tissues, the $\mathrm{P}_{\mathrm{O}_{2}}$ falls further as oxygen traverses the intracellular structures. Indeed, inside the mitochondria the $\mathrm{P}_{\mathrm{O}_{2}}$ is below $10 \mathrm{~mm} \mathrm{Hg} .{ }^{27}$

Importantly, there are regional differences in oxygen extraction and oxygen utilization. This results in quite a range of regional $\dot{\mathrm{V}}_{\mathrm{O}_{2}}$ values and regional values for venous $\mathrm{P}_{\mathrm{O}_{2}}$. Examples of this are given in the Table. ${ }^{31}$ Note that, at rest, cardiac muscle has the highest $\mathrm{O}_{2}$ extraction rate of any organ system, and skin has the lowest. As a fraction of total body oxygen consumption, skeletal muscle consumes the most oxygen, with brain and liver close behind. Different regions thus can be expected to 
have different responses and tolerances for impaired $\mathrm{O}_{2}$ delivery.

Under high oxygen demands (eg, exercise), oxygen delivery in normal subjects can increase several-fold. ${ }^{1,26}$ This is accomplished by an increase in cardiac output (both stroke volume and heart rate) as well as an increase in alveolar ventilation. Regional pulmonary vasoconstriction may also occur to optimize ventilation-perfusion matching. The systemic distribution of perfusion also adjusts to assure oxygen is delivered where it is needed most (eg, skeletal muscles) and away from organs that do not need it (eg, skin or reproductive organs). Tissue global oxygen extraction in normal subjects can also increase to $>60 \%$ of the delivered $\mathrm{O}_{2}$, but, again, there can be substantial regional differences. ${ }^{1,26}$

If oxygen delivery is compromised (hypoxic environment or diseases of the cardiorespiratory system), compensatory respiratory and cardiac mechanisms described above for high $\mathrm{O}_{2}$ demand states are similarly activated. ${ }^{31-33}$ Over time, other compensatory mechanisms also emerge. Hypoxemia will stimulate increased red blood cell production and an increase in red blood cell 2,3diphosphoglycerate (2,3-DPG) to facilitate $\mathrm{O}_{2}$ unloading in the tissues. ${ }^{33,34}$ In the cells, hypoxia inducible factor 1 (HIF1), a hetero-dimeric protein, plays a critical role in the response to hypoxia. ${ }^{33,34}$ HIF1 results in up-regulation of erythropoietin, angiogenic factors, vasoactive mediators, activation of glycolytic enzymes to produce anaerobic metabolism, and even a mitochondrial hibernation phenomenon resulting in decreased oxygen demands. Recent work has also implicated endogenous carbon monoxide and $\mathrm{H}_{2} \mathrm{~S}$ as mediators of intracellular hypoxic protection. ${ }^{33}$

In healthy individuals in hypoxemic environments, these compensatory mechanisms can be quite effective. Classic examples include the ability of humans to live at very high altitudes with $\mathrm{P}_{\mathrm{O}_{2}}$ values of $50 \mathrm{~mm} \mathrm{Hg}$ or less. ${ }^{32,35,36} \mathrm{Sim}-$ ilarly, the developing fetus near delivery has $\mathrm{P}_{\mathrm{aO}_{2}}$ values often below $30 \mathrm{~mm} \mathrm{Hg} .{ }^{37}$ It is clear that, with proper compensatory mechanisms, human life can thrive with $\mathrm{P}_{\mathrm{O}_{2}}$ values lower than traditional clinical thresholds of $55^{-}$ $60 \mathrm{~mm} \mathrm{Hg}$.

In diseased individuals, however, many of these compensatory mechanisms may be blunted. Systemic inflammation and organ dysfunction may impair ventilation, create poor ventilation-perfusion matching, limit cardiac function, disrupt proper control of systemic perfusion distribution, impair tissue oxygen extraction, and limit the hemoglobin response. ${ }^{38,39}$ Tolerance to low levels of $\mathrm{O}_{2}$ content and $\mathrm{P}_{\mathrm{O}_{2}}$ in disease states is thus likely to be reduced, compared to healthy individuals, although this will be variable, depending on the patient's compensatory capabilities and oxygen demands. For example, an otherwise healthy individual in the ICU with low oxygen demands (eg, a hypothermic drowning victim) might be expected to tol-

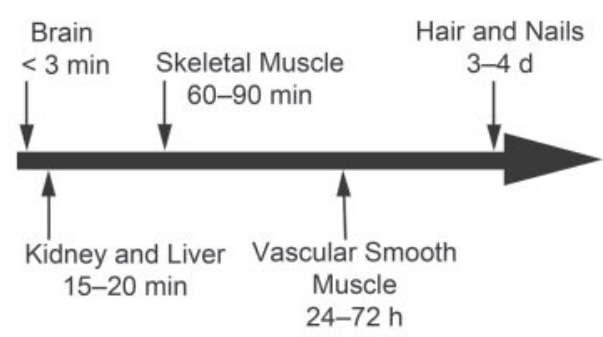

Figure. Relative tolerance to severe hypoxia in different tissues. (Data from Reference 32.)

erate much lower oxygenation levels than an elderly septic patient with high oxygen demands. Similarly, the longterm oxygen studies of the 1970s clearly showed a mortality benefit to keeping $\mathrm{P}_{\mathrm{aO}_{2}}$ above $55 \mathrm{~mm} \mathrm{Hg}$ in patients with severe chronic lung disease. ${ }^{40}$

At the end of the day, in trying to balance adequate oxygenation goals with the potential toxicities of oxygenation support strategies, the key clinical question is what level of tissue hypoxia results in serious tissue injury. A number of important metabolic processes are affected by intracellular oxygen tension. ${ }^{32}$ However, when these hypoxic effects become clinically meaningful in different tissues is not clear. From an overall perspective, the brain is the organ most exquisitely sensitive to injury from hypoxia (Figure). ${ }^{32}$ Both animal and human studies suggest that intracellular $\mathrm{P}_{\mathrm{O}_{2}}$ values in brain tissue below $10-15 \mathrm{~mm} \mathrm{Hg}$ are injurious. ${ }^{41}$ Brain injury is also associated with oxyhemoglobin saturation $<50-54 \%$ in blood sampled in the jugular venous system. ${ }^{42}$ Whether brain oxygenation is the best guide to systemic oxygenation management, however, needs further clinical outcome studies.

\section{So What Are Reasonable Oxygenation Targets Today?}

As noted above, the clinical goal is to balance adequate tissue oxygenation against oxygenation support toxicities. In the patient with severe hypoxemic respiratory failure this may mean reassessing oxygenation goals in order to provide the safest support. A number of approaches have been described over the last half century. ${ }^{43}$

Traditional oxygenation support targets have focused heavily on monitoring what the cardiorespiratory system is delivering: arterial $\mathrm{P}_{\mathrm{O}_{2}}$, arterial $\mathrm{O}_{2}$ content, and cardiac output. Commonly recommended targets have been an arterial $\mathrm{P}_{\mathrm{O}_{2}}$ of $>55 \mathrm{~mm} \mathrm{Hg}$, hemoglobin levels of at least $7 \mathrm{~g} / \mathrm{dL}$ (but perhaps as high as $9-10 \mathrm{~g} / \mathrm{dL}$ in high $\mathrm{O}_{2}$ demand states), and cardiac indices above $2 \mathrm{~L} / \mathrm{min} / \mathrm{m}^{2}$. These targets will keep $\mathrm{O}_{2}$ delivery near normal. ${ }^{1,26}$ It is clear from the discussion above, however, that these parameters are insensitive and nonspecific indicators of "safe" oxygenation at the tissue level, and efforts to normalize 
these values may force excessive use of potentially harmful oxygenation support strategies. ${ }^{34-46}$

Tissue $\mathrm{O}_{2}$ utilization monitoring $\left(\dot{\mathrm{V}}_{\mathrm{O}_{2}}\right)$ might offer more in-depth assessments of overall body oxygenation status than simple $\mathrm{O}_{2}$ delivery. Using this approach, $\mathrm{O}_{2}$ delivery could be deemed adequate if total body $\dot{\mathrm{V}}_{\mathrm{O}_{2}}$ was adequate $(250 \mathrm{~mL} / \mathrm{min}$ in a normal metabolic state: perhaps higher in sepsis, perhaps lower in the presence of paralytics). Indeed, a number of clinical studies in the last 2 decades argued that $\mathrm{D}_{\mathrm{O}_{2}}$ should be increased until $\dot{\mathrm{V}}_{\mathrm{O}_{2}}$ is no longer increased. ${ }^{47}$

Because assessments of $\mathrm{D}_{\mathrm{O}_{2}}$ and $\dot{\mathrm{V}}_{\mathrm{O}_{2}}$ utilize common variables (cardiac output and arterial $\mathrm{O}_{2}$ content), the use of simply the mixed venous $\mathrm{P}_{\mathrm{O}_{2}}$ or mixed venous oxyhemoglobin saturation has been proposed as a more focused assessment of tissue oxygenation. ${ }^{48,49}$ With this approach, a mixed venous $\mathrm{P}_{\mathrm{O}_{2}}$ above $40 \mathrm{~mm} \mathrm{Hg}$ or mixed venous oxyhemoglobin saturation above $70 \%$ (so called "goal directed" therapy) ${ }^{50}$ might suggest the presence of adequate oxygen delivery. Importantly, this approach assumes oxygen extraction capabilities are near normal—something that might not be present in a severe systemic inflammatory response state. Serum lactate has also been suggested as a monitor for global adequacy of $\mathrm{O}_{2}$ delivery. ${ }^{51}$ It must always be remembered that with all of these assessment approaches the clinician is measuring a global number, not a regional number. Specific tissue beds could still have substantial tissue hypoxia whose effects are diluted in global measurements and thus not clinically appreciated.

Conceptually, then, the ideal way to guide oxygenation support would be to monitor the tissue $\mathrm{P}_{\mathrm{O}_{2}}$ in critical organs such as the brain. ${ }^{52}$ This could involve the use of direct intracerebral tissue $\mathrm{P}_{\mathrm{O}_{2}}$ sensors. ${ }^{26,35,36}$ More indirect measurements could be jugular bulb venous $\mathrm{P}_{\mathrm{O}_{2}}$ or venous oxyhemoglobin saturation, or near infrared spectroscopy using sensors placed on the forehead. ${ }^{36}$ Direct cerebral tissue monitoring, unfortunately, requires invasive, technically complex systems, and the noninvasive near infrared surface sensor has important technical limitations relating to artifacts from scalp and skull metabolism.

One could also argue that hypoxic effects in other critical organs might also be important to monitor, and, indeed, a number of options exist. ${ }^{32-34}$ For example, gut $\mathrm{pH}$ could be a useful marker for the development of bacterial translocation across hypoxemic gastrointestinal tissue, ${ }^{53}$ renal tubular function could be an important marker for the development of hypoxic acute kidney injury, cardiac ischemic markers could be useful indicators of hypoxic cardiac injury, and liver function could be a useful indicator of hypoxic hepatic injury. As we move into the future and explore better ways to monitor the effects of lowering the aggressiveness of oxygenation support strat- egies, understanding these specific tissue oxygenation states would seem critical.

\section{Balancing Benefits and Risks of Specific Oxygenation Support Strategies}

Regardless of the oxygenation target, it is important to remember that, at the present time, the most effective way to treat tissue hypoxia is through manipulation of the various global oxygen delivery parameters. It is thus important to look at the relative benefits and risks of each of these manipulations in choosing which to use. For example, a $\mathrm{P}_{\mathrm{O}_{2}}$ increasing from 45 to $68 \mathrm{~mm} \mathrm{Hg}$ (a $50 \%$ increase) results in a $22 \%$ increase in oxygen delivery; a $\mathrm{P}_{\mathrm{O}_{2}}$ rising from 68 to $124 \mathrm{~mm} \mathrm{Hg}$ (an 82\% increase), however, results in oxygen delivery increase of only $9 \%$. Each of these manipulations will produce variable levels of $\mathrm{F}_{\mathrm{IO}_{2}}$ or mean airway pressure elevations that may or may not produce undesirable toxicities. Raising hemoglobin from 7 to $10 \mathrm{~g} / \mathrm{dL}$ (a $43 \%$ increase) results in a $48 \%$ increase in oxygen delivery. However, this exposes the patient to risks noted above associated with transfusions. And, finally, a cardiac output increasing from 4 to $6 \mathrm{~L} / \mathrm{min}$ (a $50 \%$ increase) results in a 50\% increase in oxygen delivery. However, this may require undesirable levels of ionotropic support.

An alternative way to manipulate tissue oxygenation is to manipulate oxygen consumption. On a global level, this can be done through pain management, fever control, agitation control, neuromuscular blockade, or cooling. ${ }^{54,55}$ Each of these, to varying degrees, can lower $\mathrm{O}_{2}$ demands in specific tissue beds to improve regional tissue oxygenation. These manipulations, however, can have their own toxicities. For example, narcotics and anxiolytics can prolong the need for mechanical ventilation, ${ }^{56}$ and neuromuscular blockade can lead to respiratory muscle disuse atrophy. ${ }^{57}$

In the future, techniques to manipulate the distribution of tissue perfusion and regional oxygen extraction may also appear. One example is the use of S-nitrosohemoglobin to selectively target oxygen delivery to tissues in most need of oxygen. ${ }^{58}$

\section{Summary}

Strategies to support oxygenation can cause substantial harm through lung stretch injury, oxygen toxicity, transfusion risks, and cardiac over-stimulation. Traditional goals of maintaining near normal arterial oxygen content and systemic oxygen delivery are most likely overly simplistic, and are insensitive and nonspecific for tissue hypoxic effects. In order to reduce iatrogenic harm, it is conceivable that clinicians could be comfortable with lower levels of arterial oxygen content (ie, oxyhemoglobin values of 
$<88 \%$ : permissive hypoxemia), provided that there are ways to monitor tissue hypoxia to assess the adequacy of compensatory mechanisms and the ability of important organs to tolerate tissue hypoxia. In the brain, the most oxygen sensitive of all human tissue, there are a number of exciting potential monitors for this purpose. Monitoring other tissues may also be important, especially the kidney and the gut, two organs in which hypoxic injury can potentiate multi-organ failure. We can learn more about hypoxia compensatory mechanisms from the fetus and from high altitude residents. We also need to learn better ways of monitoring tissue hypoxia, especially in "mission critical" tissues. In the end, however, clinical trials focused on important short and long-term outcomes will be necessary to show which oxygenation targets best allow the safest use of current support strategies.

\section{REFERENCES}

1. Murray JF. Gas exchange and oxygen transport. In; Murray JF, The normal lung, 2nd edition. Philadelphia: WB Saunders; 1986: 183-210.

2. Jenkinson SG. Oxygen toxicity. New Horiz 1993;1(4):504-511.

3. Plataki M, Hubmayr RD. The physical basis of ventilator-induced lung injury. Expert Rev Respir Med 2010;4(3):373-385.

4. Gattinoni L, Protti A, Caironi P, Carlesso E. Ventilator-induced lung injury: the anatomical and physiological framework Crit Care Med 2010;38(10 Suppl):S539-S548.

5. Schoemaker WC, Appel PL, Kram HB, Waxman K, Lee TS. Prospective trial of supranormal values of survivors as therapeutic goals in high-risk surgical patients. Chest 1988;94(6):1176-1186.

6. Hayes MA, Timmins AC, Yan EHS, Palazzo M, Hinds CJ, Watson D. Elevations of systemic oxygen delivery in the treatment of critically ill patients. N Engl J Med 1994;330(24):1717-1722.

7. Marik PE, Sibbald WJ. Effect of stored blood transfusion on oxygen delivery in patients with sepsis. JAMA 1993;269(23):3024-3029.

8. Sayah DM, Looney MR, Toy P. Transfusion reactions: newer concepts on the pathophysiology, incidence, treatment, and prevention of transfusion-related acute lung injury. Crit Care Clin 2012;28(3): 363-372.

9. Anzueto A, Frutos-Vivar F, Esteban A, Alía I, Brochard L, Stewart $\mathrm{T}$, et al. Incidence, risk factors and outcome of barotrauma in mechanically ventilated patients. Intensive Care Med 2004;30(4): 612-619.

10. Hager DN, Krishnan JA, Hayden DL, Brower RG; ARDS Clinical Trials Network. Tidal volume reduction in patients with acute lung injury when plateau pressures are not high. Am J Respir Crit Care Med 2005;172(10):1241-1245.

11. Gajic O, Dara SI, Mendez JL, Adesanya AO, Festic E, Caples SM, et al. Ventilator-associated lung injury in patients without acute lung injury at the onset of mechanical ventilation. Crit Care Med 2004; 32(9): 1817-1824.

12. Vaporidi K, Voloudakis G, Priniannakis G, Kondili E, Koutsopoulos A, Tsatsanis C, Georgopoulos D. Effects of respiratory rate on ventilator-induced lung injury at a constant $\mathrm{P}_{\mathrm{aCO}}$ in a mouse model of normal lung. Crit Care Med 2008;36(4):1277-1283.

13. Rich BR, Reickert CA, Sawada S, Awad SS, Lynch WR, Johnson $\mathrm{KJ}$, Hirschl RB. Effect of rate and inspiratory flow on ventilator induced lung injury. J Trauma 2000;49(5):903-911.

14. Webb HJH, Tierney DF. Experimental pulmonary edema due to intermittent positive pressure ventilation with high inflation pres- sures: protection by positive end-expiratory pressure. Am Rev Respir Dis 1974;110(5):556-526.

15. Crotti S, Mascheroni D, Caironi P, Pelosi P, Ronzoni G, Mondino M, et al. Recruitment and derecruitment during acute respiratory failure. Am J Respir Crit Care Med 2001;164(1):131-140.

16. Rimensberger PC, Prisine G, Mullen BM, Cox PN, Slutsky AS. Lung recruitment during small tidal volume ventilation allows minimal positive end expiratory pressure without augmenting lung injury. Crit Care Med 1999;27(9):1940-1945.

17. Trembly L, Valenza F, Ribiero SP, Li J, Slutsky AS. Injurious ventilatory strategies increase cytokines and C-fos MRNA expression in an isolated rat lung model. J Clin Invest 1997;99(5):944-952.

18. Ranieri VM, Suter PM, Totorella C, De Tullio R, Dayer JM, Brienza A, et al. Effect of mechanical ventilation on inflammatory mediators in patients with acute respiratory distress syndrome. JAMA 1999; 282(1):54-61.

19. Nahum A, Hoyt J, Schmitz L, Moody J, Shapiro R, Marini JJ. Effect of mechanical ventilation strategy on dissemination of inter-tracheally instilled E. coli in dogs. Crit Care Med 1997;25(10):1733-1743.

20. Fracica PJ, Knapp MJ, Pantadosi CA, Takeda K, Fulkerson WJ, Coleman RE, et al. Responses of baboons to prolonged hyperoxia: physiology and qualitative pathology. J Appl Physiol 1991;71(6): 2352-2362.

21. Crapo JD, Hayatdavoudi G, Knap MJ, Fracica PJ, Wolfe WG, Piantadosi CA. Progressive alveolar septal injury in primates exposed to $60 \%$ oxygen. Am J Physiol 1994;267(6):L797-L806.

22. Iscoe S, Beasley R, Fisher JA. Supplementary oxygen for nonhypoxemic patients: $\mathrm{O}_{2}$ much of a good thing? Crit Care 2011;15(3): 305-309.

23. Isaza G, Arora S Incidence and severity of retinopathy of prematurity in extremely premature infants. Can J Ophthalmol 2012;47(3): 296-300.

24. Kones R. Oxygen therapy for acute myocardial infarction: then and now. A century of uncertainty. Am J Med 2011;124(11):1000-1005.

25. de Graaff AE, Dongelmans DA, Binnekade JM, de Jonge E. Clinicians' response to hyperoxia in ventilated patients in a Dutch ICU depends on the level of $\mathrm{F}_{\mathrm{IO}_{2}}$. Intensive Care Med 2011;37(1):46-51.

26. de Jonge E, Peelen L, Keijzers P. Association between administered oxygen, arterial partial oxygen pressure and mortality in mechanically ventilated intensive care unit patients. Crit Care 2008;12:R156.

27. Neumar RW. Optimal oxygenation during and after cardiopulmonary resuscitation. Curr Opin Crit Care 2011;17(3):236-240.

28. Kilgannon JH, Jones AE, Shapiro NI, Angelos MG, Milcarek B, Hunter K, et al; Emergency Medicine Shock Research Network (EMShockNet) Investigators. Association between arterial hyperoxia following resuscitation from cardiac arrest and in-hospital mortality. JAMA 2010;303(21):2165-2171.

29. Bellomo R, Bailey M, Eastwood GM, Nichol A, Pilcher D, Hart GK, et al; Study of Oxygen in Critical Care (SOCC) Group. Arterial hyperoxia and in-hospital mortality after resuscitation from cardiac arrest. Crit Care 2011;15(2):R90.

30. Eastwood G, Bellomo R, Bailey M, Taori G, Pilcher D, Young P, Beasley R. Arterial oxygen tension and mortality in mechanically ventilated patients. Intensive Care Med 2012;38(1):91-98.

31. Finch CA, Lenfant C. Oxygen transport in man. N Engl J Med 1972;286(8):407-415.

32. Leach RM, Treacher DF. Oxygen transport: 2: tissue hypoxia. BMJ 1998;317(7169):1370-1373.

33. Martin DS, Khosravi M, Grocott M, Mythen MG. Concepts in hypoxia reborn. Crit Care 2010;14(4):315.

34. Schumacker PT. Hypoxia-inducible factor-1 (HIF-1). Crit Care Med 2005;33(12 Suppl):S423-S425. 
35. Martin D, Windsor J. From mountain to bedside: understanding the clinical relevance of human acclimatization to high-altitude hypoxia. Postgrad Med J 2008;84(998):622-627.

36. Beall CM. Andean, Tibetan, and Ethiopian patterns of adaptation to high-altitude hypoxia. Integr Comp Biol 2006;46(1):18-24

37. Richardson BS, Bocking AD. Metabolic and circulatory adaptations to chronic hypoxia in the fetus. Comp Biochem Physiol A Mol Integr Physiol 1998;119(3):717-723.

38. Ruokonen E, Takala J, Kari A, Saxén H, Mertsola J, Hansen EJ. Regional blood flow and oxygen transport in septic shock. Crit Care Med 1993;21(9):1296-1303.

39. DeBacker D, Creteur J, Preiser JC, Dubois MJ, Vincent JL. Microvascular blood flow is altered in patients with sepsis. Am J Respir Crit Care Med 2002;166(1):98-104.

40. Nocturnal Oxygen Therapy Trial Group. Continuous or nocturnal oxygen therapy in hypoxemic chronic obstructive lung disease: a clinical trial. Ann Intern Med 1980;93(3):391-398.

41. Purins K, Enblad P, Wiklund L, Lewén A. Brain tissue oxygenation and cerebral perfusion pressure thresholds of ischemia in standardized pig brain death model. Neurocrit Care 2012;16(3):462-469.

42. Ponce LL, Navarro JC, Robertson CS. Advanced bedside neuromonitoring. In: Vincent JL, Abraham E, Moore FA, Kochanek PM, Fink MP, editors. Textbook of critical care, 6th edition. Philadelphia: Elsevier; 2011:146-152.

43. Third European Consensus Conference in Intensive Care Medicine. Tissue hypoxia: how to detect, how to correct, how to prevent. Am J Respir Crit Care Med 1996;154(5):1573-1578.

44. Cheifetz IM, Hamel DS. Is permissive hypoxemia a beneficial strategy for pediatric acute lung injury? Respir Care Clin N Am 2006; 12(2):359-369.

45. Abdelsalam M, Cheifetz IM. Goal-directed therapy for severely hypoxic patients with acute respiratory distress syndrome: permissive hypoxemia. Respir Care 2010;55(11):1483-1490.

46. Abdelsalam M. Permissive hypoxemia: is it time to change our approach? Chest 2006;129(1):210-211.

47. Vincent JL, De Backer D. Oxygen transport-the oxygen delivery controversy. Intensive Care Med 2004;30(11):1990-1996.
48. Walley KR. Use of central venous oxygen saturation to guide therapy. Am J Respir Crit Care Med 2011;184(5):514-520.

49. van Beest P, Weitasch G, Sheeren T, Spronk P, Kuiper M. Clinical review: use of venous oxygen saturations as a goal: a yet unfinished puzzle. Crit Care 2011;15(5):232-240

50. Otero RM, Nguyen HB, Huang DT, Gaieski DF, Goyal M, Gunnerson KJ, et al. Early goal-directed therapy in severe sepsis and septic shock revisited: concepts, controversies, and contemporary findings. Chest 2006;130(5):1579-1595.

51. Bakker J, Coffernils M, Leon M, Gris P, Vincent JL. Blood lactate levels are superior to oxygen-derived variables in predicting outcome in human septic shock. Chest 1991;99(4):956-962.

52. Carreau A, El Hafny-Rahbi B, Matejuk A, Grillon C, Kieda C. Why is the partial pressure of human tissues a critical parameter? Small molecules and hypoxia. J Cell Mol Med 2011;15(6):1239-1253.

53. Gutierrez GN, Palizas F, Doglio G, Wainsztein N, Gallesio A, Pacin J, et al. Gastric intramucosal $\mathrm{pH}$ as a therapeutic index of tissue oxygenation in critically ill patients. Lancet 1992;339(8787): 195-199.

54. Papazian L, Forel JM, Gacouin A, Penot-Ragon C, Perrin G, Loundou A, et al; ACURASYS Study Investigators. Neuromuscular blockers in early acute respiratory distress syndrome. N Engl J Med 2010; 363(12):1107-1116.

55. Manthous CA, Hall JB, Olson D, Singh M, Chatila W, Pohlman A, et al. Effect of cooling on oxygen consumption in febrile critically ill patients. Am J Respir Crit Care Med 1995;151(1):10-14.

56. Hooper MH, Girard TD. Sedation and weaning from mechanical ventilation: linking spontaneous awakening trials and spontaneous breathing trials to improve patient outcomes. Anesthesiol Clin 2011; 29(4):651-661.

57. Vassilakopoulos D, Petrof B. Ventilator induced diaphragmatic dysfunction. Am J Respir Crit Care Med 2004;169(3):336-341.

58. Sonveaux P, Lobysheva II, Feron O, McMahon TJ. Transport and peripheral bioactivities of nitrogen oxides carried by red blood cell hemoglobin: role in oxygen delivery. Physiology (Bethesda) 2007; 22:97-112.

\section{Discussion}

Kevin Ward: I'm going to challenge you on one notion. I think it's sort of counterintuitive, but I would pick the brain as the last organ to target, because of its ability to compensate. In a critical care state I think the splanchnic bed would reach a level of dysoxia prior to the brain. What say you?

MacIntyre: I'd rather have a brain than a stomach. I'm going to agree that the brain is capable of picking up extraction, perhaps more than the splanchnic bed, but at the end of the day the demands on the brain, its susceptibility to injury, and the consequences of brain injury are so pro- found that I think that's where I'd put my money. It is the most "mission critical" organ.

Treggiari: I think the brain, in general, is already extracting a high $\mathrm{O}_{2}$ fraction, and that's why venous saturation is lower in the jugular vein than anywhere else in the body. This also explains why the superior vena cava has lower saturation than the inferior vena cava. There is less extraction reserve for the brain than for other organs. One of the purposes of neuroresuscitation is to try to "rest" the brain by reducing extraction, using interventions such as sedation and paralysis and other manipulations to allow brain metabolism to be less active.
Kevin Ward: Although this is not well appreciated, the splanchnic bed's extraction is almost identical to that of the brain. The important issue is the ability to increase blood flow to maintain oxygen extraction. And consumption is better in the brain because of autoregulatory mechanisms than it is to the splanchnic bed. So if you believe the splanchnic bed is the motor of multi-organ failure, then you might get in trouble by looking at the brain to tell you when you're past critical $\mathrm{O}_{2}$ delivery.

MacIntyre: I'm going to move away from the brain's ability to compensate or not compensate. I think in terms of the consequences of hypoxia and the ability to tolerate hypoxia, the brain 
seems considerably more fragile than the gut. Having said that, I would agree that hypoxia effects in other organs, such as the gut and kidney, could be very important in "feeding" multiorgan failure, and these hypoxia thresholds may be different than the brain.

Kallet: I think another way to approach this is to look at muscle tissue oxygenation. ${ }^{1}$ In trauma patients you're worried about splanchnic perfusion, and if the gut is in danger, one of the first tissue beds affected is the limb muscles. This has been demonstrated in animal models of hemorrhagic shock, and monitoring muscle tissue $\mathrm{P}_{\mathrm{O}_{2}}$ might be a better way to approach, or at least to balance, the problem.

MacIntyre: Evolution has given us a system that seems to want to protect the brain. That's why the blood flow goes there. And I agree with you that an ischemic gut is the "fuel" and the liver is the "engine" of multi-organ failure. I don't mean I want to sacrifice the gut. My point is that I think the brain remains the least tolerant of hypoxia.

Kevin Ward: And I agree with you. My point is that if your gut or peripheral venous saturations are good, it's likely that your brain is OK.

Criner: So, keeping with the theme that the brain is the most important, are there data that show that hyperoxia causes brain injury?

\section{MacIntyre: Hyperoxia?}

Criner: Yeah: to go back to the sweet spot of where we should be.

MacIntyre: Certainly, reperfusion injury has been well described and is potentiated by hyperoxia. We saw some excellent slides earlier of that occurring in the cardiac muscles. It probably happens in other organs, but I'm not an expert in this field.

Treggiari: To my knowledge, there is no evidence of hyperoxia-induced brain injury, but there are some experimental data suggesting that increasing free $\mathrm{O}_{2}$ radicals is deleterious to the brain. ${ }^{2}$ However, this topic is not very well explored, so drawing conclusions would be premature. Some preliminary data suggest that normobaric hyperoxia improves cerebral metabolism and reduces intracranial pressure in patients with severe brain injury. ${ }^{3}$

MacIntyre: I think one thing we've learned today is that hyperoxia is not only unnecessary, but is very likely dangerous. And there's no reason to believe that that wouldn't be true in the brain as it is in other organs.

Jeff Ward: Is there any evidence for therapeutic hypothermia with permissive hypoxemia? ${ }^{4}$

MacIntyre: That's an interesting question. It speaks to the issue of lowering $\mathrm{O}_{2}$ consumption to a sort of hibernation state, if you will. And there are ample data that lowering $\mathrm{O}_{2}$ demand improves intracellular oxygenation. There is a lot of interest in using hypothermia in acutely ischemic states like witnessed ventricular fibrillation, which has shown rather impressive improvements in survival.

Jeff Ward: And isn't there another biochemical connection, beyond just lowered $\mathrm{O}_{2}$ consumption?

MacIntyre: Yes, it's not just $\mathrm{O}_{2}$ consumption: it puts the cellular metabolism into a hybernative state.

Jeff Ward: Am I correct that glutamate and calcium are also involved in mediating central-nervous-system effects after circulatory arrest? ${ }^{4-6}$
MacIntyre: I'm not sure and wouldn't want to misspeak.

Kallet: I think the context of all of this is something like permissive hypoxia or lowering the core temperature to do that. But for how long? If you keep somebody hypothermic, the risk of pneumonia goes up. How do you balance those?

MacIntyre: The clinical trials on hypothermia have usually applied hypothermia for 24 to 48 hours. Papazian's study $^{7}$ using routine neuromuscular blockade was 48 hours. That doesn't mean that going longer is necessarily bad, but that's what the data are.

Treggiari: In the neurocritical setting, mild hyperthermia has been studied in subarachnoid hemorrhage ${ }^{8}$ and traumatic brain injury, ${ }^{9}$ and neither of those large trials showed a benefit with hypothermia. One reason the subarachnoid hemorrhage population did not benefit from hypothermia is that the intervention was only implemented intra-operatively, for 68 hours, and the rewarming was done relatively quickly. So it remains a matter of debate whether the lack of benefit was due to the short duration or whether there really is no benefit.

1. Wan JJ, Cohen MJ, Rosenthal G, Haitsma IK, Morabito DJ, Knudson MM, Manley GT. Refining resuscitation strategies using tissue oxygen and perfusion monitoring in critical organ beds. J Trauma 2009;66(2): 353-357.

2. Niatsetskaya ZV, Sosunov SA, Matsiukevich D, Utkina-Sosunova IV, Ratner VI, Starkov AA, et al. The oxygen free radicals originating from mitochondrial complex I contribute to oxidative brain injury following hypoxia-ischemia in neonatal mice. J Neurosci 2012;32(9):3235-3244.

3. Tolias CM, Reinert M, Seiler R, Gilman C, Scharf A, Bullock MR. Normobaric hyperoxia-induced improvement in cerebral metabolism and reduction in intracranial pressure in patients with severe head injury: a prospective historical cohortmatched study. J Neurosurg 2004;101(3): 435-444. 


\section{Supporting Oxygenation in Acute Respiratory Failure}

4. Hypothermia After Cardiac Arrest Study Group. Mild therapeutic hypothermia to improve the neurologic outcome after cardiac arrest. N Engl J Med 2002;346(8):549-556. Erratum in: NEngl J Med 2002;346(22):1756.

5. Bernard SA, Gray TW, Buist MD, Jones BM, Silvester W, Guttridge G, Smith K. Treatment of comatose survivors of outof-hospital cardiac arrest with induced hypothermia. N Engl J Med 2002;346(8): 557-563.
6. Tseng EE, Brock MV, Lange MS, Troncoso JC, Blue ME, Lowenstein CJ, et al. Glutamate excitotoxicity mediates neuronal apoptosis after hypothermic circulatory arrest. Ann Thorac Surg 2010;89(2):440-445

7. Papazian L, Forel JM, Gacouin A, PenotRagon C, Perrin G, Loundou A, et al; ACURASYS Study Investigators. Neuromuscular blockers in early acute respiratory distress syndrome. N Engl J Med 2010; 363(12):1107-1116
8. Todd MM, Hindman BJ, Clarke WR, Torner JC; Intraoperative Hypothermia for Aneurysm Surgery Trial (IHAST) Investigators. Mild intraoperative hypothermia during surgery for intracranial aneurysm. N Engl J Med 2005;352(2):135-145.

9. Clifton GL, Miller ER, Choi SC, Levin HS, McCauley S, Smith KR Jr, et al. Lack of effect of induction of hypothermia after acute brain injury. N Engl J Med 2001; 344(8):556-563. 